Klujev, A.S. (2021). Nikolai Onufrievich Lossky's intuitivism: philosophy of music. Philosophical thought of the 21st century: if there is a future for philosophy. Collection of Scientific Articles. European Scientific e-Journal, 9 (15), 27-39. Hlučín: "Anisiia Tomanek" OSVĆ.

КАюев, А.С. (2021). Интуитивизм Николая Онуфриевича Аосского: философия музыки. Philosophical thought of the 21st century: if there is a future for philosophy. Collection of Scientific Articles. European Scientific e-Journal, 9 (15), 27-39. Hlučín: “Anisiia Tomanek” OSVČ.

DOI: $10.47451 /$ phi2021-10-001

The paper will be published in Crossref, ICI Copernicus, Academic Resource Index ResearchBib, J-Gate, ISI International Scientific Indexing, Zenodo, OpenAIRE, BASE, LORY, LUASA, ADL, eLibrary, and WebArchive databases.

Alexander S. Klujev, Full Professor, Doctor Habil. in Philosophy, Department of Music Upbringing and Education, A.I. Herzen State Pedagogical University. St. Petersburg, Russia.

\title{
Nikolai Onufrievich Lossky's intuitivism: philosophy of music
}

Abstract: The article reveals the features of philosophical ideas about the music of N.O. Lossky. It is established that Lossky's philosophical judgments about music are organically connected with his philosophical doctrine - intuitivism. The study purpose is to learn the philosophy of music through the Nikolai Onufrievich Lossky's intuitivism. The most important, from the point of view of the author of the article, provisions of Lossky's intuitivism are noted: 1) intuitivism provides a direct vision of the object by the knowing subject in the original, and not by means of a copy, symbol, construction, etc.; 2) intuitivism is based on intuition, acting in three types (modes): sensual, intellectual and mystical, while taking into account the legitimization of two spheres by the philosopher: the world and the Superworld (the Kingdom of God), sensual and intellectual intuition work in the world, mystical intuition prepares a breakthrough into the Superworld (the Kingdom of God). It is shown that music is an integral component - a staple - of Lossky's philosophical doctrine. It is argued that, according to Lossky, it is music that contributes to the most distinct vision of the object by the cognizing subject in the original, and the full realization of the mission intended for them by all three types of intuition. Comparative, historical and logical research methods were used to solve the tasks. The study used the works of the author, Nikolai Lossky and prominent philosophers such as B.V. Asafyev, A. Bergson, A.F. Losev, P.A. Florensky, and the memoirs of Prince E.N. Trubetskoy.

Keywords: philosophy, music, Nikolai Onufrievich Lossky, intuitivism, sensory intuition, intellectual intuition, mystical intuition, Kingdom of God.

\footnotetext{
Александр Сергеевич КАюев, профессор, Аоктор философских наук, кафедра музыкального воспитания и образования, Российский государственный педагогический университет им. А.И. Герцена. Санкт-Петербург, Россия.
}

\section{Интуитивизм Николая Онуфриевича Аосского: фимософия музыки}

Аннотаиия: В статье раскрываются особенности философских представлений о музыке Н.О. Аосского. Устанавливается, что философские суждения о музыке Аосского органично связаны с его философским учением - интуитивизмом. Целью исследования является познание философии музыки через интуитивизм Николая Онуфриевича Аосского. Отмечаются наиболее важные, с точки зрения автора статьи, положения интуитивизма Аосского: 1) интуитивизм 
обеспечивает непосредственное видение предмета познающим субъектом в подАиннике, а не посредством копии, символа, конструкции и т.п.; 2) интуитивизм базируется на интуиции, выступающей в трех типах (моАусах): чувственной, интемлектуальной и мистической, при этом, с учетом узаконивания философом двух сфер: мира и Сверхмира (Царства Божия), чувственная и интелмектуальная интуиция «работают» в мире, мистическая интуиция подготавливает прорыв в Сверхмир (Царство Божие). Показано, что музыка яв яется неотъемлемым компонентом скрепом - философского учения Аосского. УтвержАается, что, согласно Аосскому, именно музыка способоствует наиболее отчетливому видению предмета познающим суббъектом в подлиннике и полномерному осуществлению всеми тремя типами интуиции предназначенной им миссии. Аیя решения поставленных задач были использованы сравнительный, исторический и Аогический методы исследования. В ходе исследования были использованы труды автора, Николая Аосского и видных философов, таких как Б.В. Асафьев, А. Бергсон, А.Ф. Аосев, П.А. ФАоренский, а также воспоминания князя Е.Н. Трубецкого.

Ключевъе слова: философия, музыка, Николай Онуфриевич Аосский, интуитивизм, чувственная интуиция, интелмектуальная интуиция, мистическая интуиция, Царство Божие.

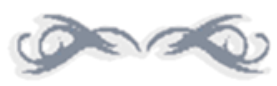

\section{Introduction}

Nikolai Onufrievich Lossky (1870-1965), whose 150th birthday we recently celebrated, showed great interest in music. At the same time, Lossky's ideas about music have not yet received proper coverage.

The peculiarity of Lossky's philosophy of music was his awareness of music as an essential component, or the staple of his philosophical doctrine - intuitivism if to be exact. To begin with, the author offers to turn to the doctrine itself.

As doctrine, intuitivism took shape in Lossky practically throughout his entire creative life. The philosopher had a "glimpse" of the idea of intuitivism back in 1898. Here is how he describes it in his "Memoirs" (this fragment is often quoted in works about Lossky): "It seems ... in the autumn of 1898, S.A. Alekseev and I were driving a cab along Gorokhovaya Street. It was a foggy day when all objects merged in the Petersburg autumn haze. I was immersed in my usual reflections: "I know only what is immanent to my consciousness, but only my mental states are immanent to my consciousness, so, I know only my mental life." I looked at the misty street in front of me and suddenly the thought flashed through my mind: "everything is immanent to everything". I immediately felt that the riddle was solved, that the development of this idea would answer all the questions that concern me" (Lossky, 2008:93-94).

The main line of development of this concept is formed by the works of Nikolai Lossky, built as follows: The Fundamental Doctrines of Psychology from the Point of View of Voluntarism (1903), The Intuitive Basis of Knowledge (1st ed., 1906), The World as an Organic Whole (1917), Sensuous, Intellectual and Mystical Intuition (the 1930s - 1940s). Thus, the most complete and harmonious model of intuitivism can be found in the Nikolai Lossky's book Sensuous, Intellectual and Mystical Intuition. The author offers to turn to this work.

The study purpose was to learn the philosophy of music through Nikolai Onufrievich Lossky' intuitivism.

Based on the purpose of the study, the following tasks were set: 
- analyze intuitivism in the interpretation of Nikolai Lossky;

- consider the phenomenon of music in the philosophy of Nikolai Lossky;

- determine the integrity features in music, which were put forward by Nikolai Lossky.

To solve the tasks, the author used comparative, historical, and logical study methods.

The research used the author's articles, the works of Nikolai Lossky and prominent philosophers such as B.V. Afanasyev, A. Bergson, A.F. Losev, P.A. Florensky, and the memoirs of Prince E.N. Trubetskoy.

\section{Intuitivism in the interpretation of Nikolai Lossky}

To begin, it is necessary to clarify what is intuitivism in Lossky's interpretation. According to Lossky, "intuitivism (provides - author) a direct vision ... of an object by a cognizing subject ... having in mind an object in the original, and not using a copy, symbol, construction, etc." (Lossky, 1999:137). With the word "intuition" the thinker means "this is a direct vision ... of the subject". As Lossky writes, his "doctrine about intuition... is a new theory... This theory, asserting that knowledge is the direct contemplation by the subject of the most authentic trans-subjective (external - author) being, puts even the most ordinary sensory perception (of the subject - author) on the same level with clairvoyance" (Lossky, 1999:138).

An important point: what is the subject of knowledge according to Lossky? Lossky has it in two dimensions - the world and the Superworld.

In Lossky's interpretation, the world has two levels: real, or real being, and ideal, or ideal being. As the thinker writes, "by the word real being, I mean events that are dynamically actively carried out in time or spatial-temporal form in that aspect of these forms, as a result of which parts of the event exist outside of each other. By the word ideal being, I mean everything free from spatial and temporal fragmentation, which ... determines the extralegal parts interpenetration, the transcendence of each of them beyond itself ... Real being ... exists only based on being ideal ... The worldview that asserts this thesis can be called ideal-realism" (Losskey, 1999:197).

According to Lossky, the Superworld "is a beginning ... (which - author) stands above all other beginnings, it ... is delimited from the world as a beginning incommensurable with the world, justifying the world, but itself is not justified by anyone and nothing... Being incommensurable with the world, it cannot be expressed and defined by any concepts borrowed from the sphere of world existence... because it is above all these definitions... Communion with the Superworld principle is a high manifestation of religious life and religious experience. In it, the Superworld principle is revealed as the super-existential fullness of being" (Lossky, 1999:260-261).

Based on the two-dimensionality of the object of cognition - the world and the Superworld - Lossky interprets the use of intuition in cognition: Lossky's intuition appears in three types that unfold sequentially: sensual, intellectual, and mystical. Sensual and intellectual intuitions "work" in the world, mystical - prepares a breakthrough into the Superworld. It should look at how sensual, intellectual and mystical intuitions manifest themselves.

Sensory intuition contributes to the cognition of the bodily being of the object. As Nikolai Lossky writes, sensory intuition determines the comprehension of "many aspects ... of the visual content of the subject ... with the participation of the senses" (Lossky, 1999:160, 174). 
According to Nikolai Lossky, intellectual intuition is directed "not to the real, but the ideal moments of the subject (and is carried out - author) ... without the direct mediation of the senses. (i.e., it is directed. - author) ... to an ideal being" (Lossky, 1999:178, 188).

The philosopher states that "because of the permeation of real being with the ideal, sensory intuition directed at the real sensory (sides of the subject - author) ... can give knowledge only in combination with intellectual intuition directed at the ideal aspects of being." And since, thanks to the use of these two types of intuition, "being defined according to the law of identity, contradiction and the excluded third is known, the certainty corresponding to these laws ... concerning knowledge can be called the logical form of objects" (Lossky, 1999:197, 259).

Mystical intuition leads from the world to the Superworld. This happens because "speculation, exploring the conditions of the possibility of logically defined objects, leads with the logical necessity to the discretion of the beginning, which stands above these objects and justifies them, being itself a super logical, metalogical being”' (Lossky, 1999:259).

Lossky's concept of substantial figures is an excellent representation of the fusion of the knower and the subject sphere.

According to Lossky, substantial figures are personalities, potential (in the subject environment) and actual (in the sphere of the knower). At the same time, according to Lossky, "substantial figures ... as individuals, potential or actual, are super-spatial and super-temporal... (tach - author) a substantial figure ... to (perform his - author) creative acts, he must be in his substantial super-qualitative basis a being standing above logical certainty, (i.e., author) a metalogical beginning" (Lossky, 1999: 159, 253, 259-260).

Substantial figures, personalities, are in close connection with each other, "thanks to which everything that one figure experiences as its manifestation exists not only for him but also for all other figures around the world" (Lossky, 1999:148). This connection is because "all of them ... are consubstantial (Lossky derives the term "consubstantial" from the concept of "consubstantial" - as interpreted by P. Florensky in his work Pillar and Affirmation of Truth (Florensky, 2012) - author)" (Lossky, 1999:149).

According to Lossky, the consubstantiality of substantial figures testifies to their unity, and since there is such a unity, "there must be a beginning that stands above substantial figures and justifies them (unity - author)" (Lossky, 1999:260). Such a beginning, according to Lossky, is a Supersubstantial, Superpersonal God ("The Superpersonal aspect of God") (Lossky, 1999:277). In Lossky's interpretation, the superpersonal God is the Embodiment of the Kingdom of God, because, as Lossky believes, it is in the Kingdom of God that "everything is immanent to everything" (Lossky, 1999:149). It should emphasize that The Kingdom of God, where, according to Lossky, "everything is immanent to everything", turns out to be the Highest Unity of substantial figures personalities (potential and actual), i.e., the Ultimate Unity of the knower and the known, and therefore the achievement of the Final Result of intuitive knowledge. Traditionally, the Kingdom of God, which Lossky writes about, is understood as the result of the evolutionary development of substantial figures, its Ultimate Goal. In particular, this is the point of view expressed by P.P. Gaydenko (Gaidenko, 2016) [1].

\section{Music in the Nikolai Lossky's philosophy}


As already mentioned, music is a staple of Lossky's doctrine. How should this statement be understood?

According to the philosopher, it is music that contributes to the perfect realization of intuitive cognition. According to Nikolai Lossky, this is because the cognizing subject and the cognition object are inextricably connected in sound. Sound is the embodiment of a complete subject fusion and the cognition object. Nikolai Lossky comes to this conclusion in the process of consistently understanding the existence of sound in the world.

So, already in the article Sound as a Specific Kingdom of Being (1917), the author declares the splendour of the sound embodiment of being, one can say, "the sound of being" (recall Plotinus' famous expression "the flowering of being"). As Lossky writes, "sound gives a considerable charm to existence" - and further - "Not only individual experiences, but also the entire inexhaustible unique individuality of a living being in the world with all the flavour of its originality can miraculously be present in sound and become accessible to the perception of other beings in it" (Lossky, 1917:30). "In sound, there is sometimes given the very inner integral core of individuality, indecomposable into any individual and not compounded of them" (Lossky, 1917:32).

Nikolai Lossky develops the idea of the "sound of being" in his other works. It was done in detail in the book The World as an Organic Whole, by the way, written in the same year as the above article. In this book, Lossky likens the integrity of phenomena in the world to a musical tone. Lossky notes: "By perceiving the tone, one can distinguish in it, for example, the quality and intensity of it. No one, however, will think that this quality and this intensity used to exist on their own, separately and independently of each other, and then met and formed a more complex whole, namely the musical tone... It is obvious, there is something directly opposite here. Initially, there is a whole, a tone that can be analyzed, which its sides can be distinguished in, but which cannot be put together from pre-existing parts. The proponent of the organic worldview imagines the whole world according to this model: every element of the world, whether it is an atom, or a soul, or an event, for example, movement, he considers as a side of the world that can be seen in it by analyzing it, which does not exist by itself, but based on the world whole ..." (Lossky, 1991b:350-351).

According to Lossky, it is in the musical tone that the unity of the subject and the object of cognition, i.e., intuitive cognition, is especially realized. Here is how he writes about it, referring to G. Werner's article in the work Sensual, Intellectual, and Mystical Intuition: "Based on experiments on the perception of tones, e.g., on the piano, he (G. Werner. - author) establishes the following four types of perception:

1) sometimes, the tone is completely perceived outside the subject, in the instrument, as an external object, a thing (Gegenstandston);

2) in other cases, the substance disappears, the tone is perceived as something spreading in space (Raumton);

3) further, the tone sometimes sounds in the hearing subject itself, it fills it, the "I" itself has become a violin, a bell, etc.;

4) finally, the elusive phase of perception consists in the undifferentiation of subjective and objective character" (Lossky, 1999:164). 
Nikolai Lossky notes the role of intuitive penetration into the depths of tone: "In this transition from in-body sensory experiences to a trans-subjective thing, various types of ... spiritual hearing are increasingly revealed" (Lossky, 1999:165).

This is most noticeable when listening to a piece of music. Thus, in the same work, the philosopher explains that the voice sound of an artist-singer, "developing in the listener's body itself in connection with the vibrations of the particles of his body, is his in-body sensation, is a sensory quality belonging to his psychophysical individuality; it can be more or less close to his "I", entering even into the sphere of his manifestations in some cases, and forming an external world for the "I", albeit an in-body world, in others. However, the sound in the air and artist's body is for the listener something quite trans-subjective, completely belonging to the outside world... The physiological process in the auditory centres of the temporal region (of the listener - author) is a stimulus that encourages (him - author) ... to the spiritual act of listening, to awareness, accompanied by identification... Thus, even sensory perception, despite the involvement of sensory stimuli in its occurrence and despite the presence of in-body sensations in it (the listener - author), there is mainly a spiritual act, mental contemplation of even sensual qualities ... There is no intuition that would be only sensual" (Lossky, 1999:163).

\section{Integrity features in music}

In this book, Nikolai Lossky convincingly shows the unity of substantial figures in music. The philosopher states that many ideas in music, "for example, the idea of an aria, can be identical for real processes, (especially - author), for many cases of performing an aria. It can be understood as follows: many figures, for example, students of a skilled artist, listening to an aria performed by him, intuitively assimilate the same idea of an aria... They freely assimilate the idea as a basis for possible acts of its realization in time. Moreover, the realization of such an idea is a free act... Having started singing, the artist may notice the acoustic hall features, or the listeners fatigue, or the presence of their special moods and interests to connect with some important social event; under the influence of these observations, he may have a new creative idea, an idea modification, which he appeared on stage with, and then even in the middle of the performance, he can proceed to the implementation of a different ideal plan than the initial one" (Lossky, 1999:240) [2].

A prerequisite for the performance of an aria, Nikolai Lossky emphasizes, is the "grasping" of its whole. The thinker notes: "Every sound of the aria, every intonation, deceleration, acceleration correspond to each other and mutually define each other, although they are separated in performance by a distance of several seconds or minutes. Such perfect coherence, impeccable coordination of the parts of the whole is possible only because the aria performance in time is based on the artists' single holistic vision of it, in which all the parts are viewed together at once without discontinuity in time" (Lossky, 1999:225).

The presence of integrity is extremely important for the entire piece of music. Talented composers saw the integrity of their work even in their minds before they recorded the work with notes [3].

The integrity of a piece of music is its essential quality. Integral, and therefore, according to Lossky, beautiful, musical works can transfer a person from the world to the Superworld - to the Kingdom of God. Lossky expressively writes about this in his work Freedom of Will (1927): 
the kingdom of being, in which "many people enjoy the perception of a beautiful piece of music together ... can be called the Kingdom of the Spirit, or the Kingdom of God" (Lossky, 1991 a:528529).

Nikolai Lossky considered Beethoven's 9th Symphony to be a grandiose example of a complete musical work. As the philosopher argued, the Symphony "is a complex and yet integral act, which all the elements (in an ideal way - author) are correlated with each other in, which (smoothly author) is carried out by many figures ... under the guidance of a conductor" (Lossky, 1999:227). Such musical compositions lead with inexorable force to the Superworld, to the Kingdom of God. And indeed: This happened to E.N. Trubetskoy when he listened to Beethoven's 9th Symphony, performed under the baton of Anton Rubinstein. A fragment from Trubetskoy's "Memoirs", in which he describes what happened to him at a concert while performing a Symphony, Lossky cites in his book The $W$ orld as the Realization of Beauty. Fundamentals of Aesthetics (the 1930-1940s). Lossky quotes: "Listening to the first movement (of the Symphony - author), I felt as if I was present at some cosmic storm: lightning flashes before my eyes, some dull underground thunder and rumble, which the foundations of the universe shake from, are heard. The soul is looking for but does not find comfort from the anxiety, which has seized it. This anxiety of hopeless world suffering and confusion runs through all the first three parts, growing, increasing... All this discord and chaos, all this world struggle in sounds, filling the soul with despair and horror, requires a different, higher resolution... Either everything that exists must fall into the abyss, or that fullness of life and joy must be found that would cover and transform into bliss all this immense sorrow of existence. But where is it, this completeness? In the first three parts, the whole world drama has sounded, you want to rise above it. (However - author) there is no resolution to world suffering... And suddenly, when you feel yourself at the very edge of a dark abyss, where the world is falling, you hear a sharp trumpet sound, some worldpushing chords, an imperious call from an otherworldly height from another plane of being... A hitherto unknown joy motif rushes pianissimo from the endless distance: the orchestra whispers to you some new solemn sounds. But now they are growing, expanding, approaching. This is no longer a vision, not a hint of another future - human voices that join one after another, a mighty choir that picks up the victorious hymn of joy, this is already authentic, this is the present. And you feel yourself lifted at once to a super stellar height, above the world, above humanity, above all the sorrow of existence...

Just a few months earlier, a dilemma inspired by Schopenhauer and Dostoevsky appeared before my youthful consciousness. Either there is a God, and in him, there is the fullness of life above the world, or it is not worth living at all. And I suddenly saw this dilemma deeply, vividly expressed in brilliant musical images. There is also something infinitely more than the formulation of a dilemma - there is a life experience of the otherworldly, - a real feeling (of the eternal - author) peace. Your thought... perceives the whole world drama from that height of eternity, where all confusion and horror are miraculously transformed into joy and peace. And you feel that (this one - author) eternal peace, which descends from above on the universe, is not the denial of life, but the fullness of life. None of the great artists and philosophers of the world felt and revealed this as Beethoven did" (Lossky, 1998:304-306). (A fragment from the "Memoirs" of E.N. Trubetskoy with clarifications is given according to the edition (Trubetskoy, 2000:155-157).) [4] 


\section{Discussion}

As part of the study of Nikolai Lossky's philosophical thought, it is necessary to do further in-depth research of his views on music and the influence of Nikolai Lossky's intuitivism on the philosophy of the 21 st century. The research of this area of his philosophical works will allow a radically new look at the philosophy of music itself as an integral part of the intangible cultural heritage of humanity.

\section{Conclusion}

Nikolai Onufrievich Lossky is certainly the most original Russian philosopher of music. While his philosophical music model both fits into the diadem of Russian philosophical thought about music and adorns it. In the articles Russian Philosophy of Music in the Time Flow and Russian Philosophy of Music in the Grip of Modernism, the author actualized the importance of music in the philosophical paradigm of social development, in the formation of which the most prominent philosopher of his time Nikolai Lossky took a significant part.

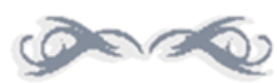

\section{References:}

Asafyev, B.V. (Glebov, I.) (1923). The process of making a sounding substance. De musica: Collection of Articles, 144-164. Petrograd.

Bergson, H. (1992). Experience about the direct data of consciousness. Collected works. In 4 vols. (trans. from French). Vol. 1. Moscow: Moscow Club.

Ermichev, A.A. (2020). I.I. Lapshin and N.O. Lossky in the journal "Der russische Gedanke". Solovyov Studies, 4, 75-93.

Florensky, P.A. (2012). The Pillar and the affirmation of Truth: The experience of Orthodox theodicy in twelve letters. Moscow: Gaudeamus; Academic Project.

Gaidenko, P.P. (2016). Hierarchical personalism of N.O. Lossky. Moscow: Political Encyclopedia.

Klujev, A.S. (2017). Russian Philosophy of Music in the Time Flow. The Russian Logos: Horizons of Comprehension. Proceedings of the International Philosophical Conference on September 25-28, 2017. In 2 vols. 2nd vol, 53-58. St. Petersburg: Intersocis, Publishing House of the Russian Christian Humanitarian Academy.

Klujev, A.S. (2019). Russian Philosophy of Music in the Grip of Modernism. Russian Logos - 2: Modern - the Boundaries of Control. Materials of the International Philosophical Conference on September 25-28, 2019, 445-447. St. Petersburg: Publishing House of the A.I. Herzen State Pedagogical University.

Losev, A.F. (1991). The main question of the philosophy of music. In: Losev A.F. Philosophy. Mythology. Culture, 315-335. Moscow: Politizdat.

Lossky, N.O. (1917). Sound as a special realm of being. In: Melos: Books about Music. Book 1, 2834. St. Petersburg.

Lossky, N.O. (1922). Bergson's intuitive philosophy. 3rd ed. St. Petersburg: Uchitel.

Lossky, N.O. (1990). The character of the Russian people. In 2 books. Book 2. Moscow: Kluch.

Lossky, N.O. (1991, a). Free will. In: Lossky, N.O. Favorites, 481-597. Moscow: Pravda. 
Lossky, N.O. (1991, b). The world as an organic whole. In: Lossky, N.O. Favorites, 335-480. Moscow: Pravda.

Lossky, N.O. (1998). The world as the realization of beauty. Basics of aesthetics. Moscow: ProgressTradition, A Tradition.

Lossky, N.O. (1999). Sensual, intellectual, and mystical intuition. Moscow: TERRA-Book Club, Republic.

Lossky, N.O. (2008). Memoirs: Life and the philosophical path. Moscow: Vikmo-Russkiy Put'.

Trubetskoy, E.N., \& Prince (2000). Memories. In: Trubetskoy, E.N., Prince. From the past. Memories. From the travel notes of a refugee, 89-226. Tomsk: Aquarius.

\section{Notes:}

[1] N.O. Lossky's intuitivism largely arose under the influence of the eponymous doctrine of A. Bergson. It can say that it was inspired by him. According to V. Yankelevich, who communicated with Bergson and was well aware of the French philosopher's doctrine, "his priority concerning Nikolai Lossky does not cause any doubt" (Ermichev, 2020:84). In his work Bergson's Intuitive Philosophy (1914), Nikolai Lossky captures the commonality and difference (as he understands them) of his and Bergson's doctrines. Thus, Lossky points out that the main features of the similarity of the doctrines are as follows: "1) ... the cognizing subject can directly contemplate the subject in the original ... 2) ... to embrace (the subject - author) with the mental eye at once as an organic whole... 3) ... justification of the organic (non-mechanistic) doctrine about the world." The main difference is that Lossky's intuitivism "is an attempt to reconcile empiricism with rationalism; he also sets the task of synthesizing positive science and metaphysics. On the contrary, Bergson pulls out the gap between science and metaphysics" (Lossky, 1922:106-107).

[2] However, according to Nikolai Lossky, the deepest penetration into the "thickness of subjectivity" occurs while listening to a folk song. Here is how Lossky discusses this in the book The Character of the Russian People (1957): "In Hunter's Notes, Turgenev has an extremely beautiful story "Singers". It describes a contest between two singers in a village tavern. Yakov, who won this competition, sang the song There $W$ as more than one Road in the Field. In his song, there was "a genuine deep passion, and youth, and strength, and sweetness, and some fascinatingly carefree, sad sorrow. Russian truthful, hot soul sounded and breathed in him, and grabbed you by the heart, grabbed right by his Russian strings". "He sang, and from every sound of his voice, there was something native and immeasurably wide, as if familiar steppe was opening up before you, going into an endless distance. I felt that my heart was boiling and tears were rising to my eyes". And other listeners, Turgenev writes, had tears in their eyes" (Lossky, 1990:34). Significantly, A. Losev writes about the same story, but in his interpretation of it (Losev, 1991:329-331).

[3] As Lossky testifies, Mozart possessed a unique ability of such discretion. In confirmation of this, the philosopher cites Mozart's well-known statement: "I keep thoughts that I like in my head and hum them to myself, at least as others notice. If I remember my thought, then immediately there appear, one after another, considerations for what it would be possible to use such a crumb to make a pate out of it, considerations about counterpoint, about the 
sound of various instruments. It heats my soul, especially, if nothing prevents me; then the thought grows and I expand and clarify it, the play turns out to be almost ready in my head, even if it is long, so that later I embrace it in my soul with one glance, like a beautiful picture or a beautiful person, and I hear it in my imagination not at all sequentially, as it should be expressed later, but as if at once, as a whole. What a party! All the invention and processing take place in me like in a beautiful dream, but such a review is best of all at once" (Lossky, 1999:225). This statement of the composer is originally interpreted by B. Asafyev (Asafyev, 1923:144).

[4] A. Bergson expresses thoughts close to N.O. Lossky about music. According to the French philosopher, the structure of musical construction embodies the architectonics of an intuitive cognitive act. In the work Time and Free Will: An Essay on the Immediate Data of Consciousness (1889), Henri Bergson argues that it is necessary to talk about the general (total) state of consciousness (defined by Bergson as pure duration - French: durée), when the previous states of consciousness are not placed "next to the present state, like points in space, but (organized like this - author), as happens when we recall the notes of some melody as if merged. Is it not possible to say that, although these notes follow each other, we still perceive them one in another, and together they resemble a living being, the various parts of which interpenetrate by virtue of their very commonality? (Thus, it can be assumed that - author) a qualitative synthesis is realized, a gradual organization of our successive sensations, a unity similar to the unity of a musical phrase" (Bergson, 1992:93, 98). The perception of an integral musical material takes us to another - a Super-world dimension; it seems to inspire us with a state of Super-Worldliness - Superstellar. Bergson points out: "Would it be possible to understand the mighty ... power of music, if we do not assume that we internally repeat audible sounds, that we seem to be plunging into a (certain - the author) state... However, this condition is original; you cannot express it; it is suggested to you." (Bergson, 1992:69) Or in another place: "The sounds of music affect us much more strongly than the sounds of nature, but this is explained by the fact that nature is limited only to the expression of feelings, whereas music inspires them to us" (Bergson, 1992:57). 